\title{
Correlation of Air Pollutants and Thermal Environment Factors in a Confined Pig House in Winter
}

\author{
Hong L. Choi*, Ki Y. Kim and Hyunook Kim ${ }^{1}$ \\ School of Agricultural Biotechnology, Seoul National University, Seoul 151-921, Korea
}

\begin{abstract}
Optimal management of indoor air quality in a confined pig house, especially in winter, is indispensable for preventing infectious respiratory disease to workers and animals. This study was performed to elucidate the correlation of aerial contaminants and climate factors in a confinement. It was observed that indoor air contaminants in the confinement was the highest at 2:00-5:00 pm in a day, followed by 8:00-11:00 pm and 8:00-11:00 am. This was attributed to the increase of pig activities in the afternoon. The concentration of total dust and total airborne bacteria was found to have a significant correlation with temperature and relative humidity $(\mathrm{p}<0.05)$. Correlation of total dust and total airborne bacteria, total dust and ammonia, and total dust and odor were shown statistically significant at $95 \%$ confidence level. In conclusion, temperature and total dust concentration correlated significantly with all the parameters except for hydrogen sulfide $\left(\mathrm{H}_{2} \mathrm{~S}\right)$. This could be explained by the fact the dryness of pig feces by increase of interior temperature and resuspension of feed deposited on the floor by the pig activity, resulted in high generation of dust which adsorbed and carried the airborne bacteria and odor compounds in a confined pig house. It was proved that the adsorptive capacity of dust with ammonia $\left(\mathrm{NH}_{3}\right)$ was higher than that with hydrogen sulfide $\left(\mathrm{H}_{2} \mathrm{~S}\right)$. (Asian-Aust. J. Anim. Sci. 2005. Vol 18, No. 4 : 574-579)
\end{abstract}

Key Words : Total Dust, Total Airborne Bacteria, Odor, Ammonia, Hydrogen Sulfide

\section{INTRODUCTION}

As an intensive and large-scale pig production system has progressed for economic reason, the confinement of pig houses, of which aerial environment is more controllable, has greatly expanded in recent years. Because a confined structure is designed to house as many pigs as possible in a limited space, their excretions and feed residuals can accumulate indoor, resulting in generation of particulates and gases which are hazardous to workers and animals (Clark et al., 1983; Arnink et al., 1999). Particulates suspended in aerial space of a pig house include dust and airborne microorganisms (Carpenter et al., 1986; Henschler, 1990). Airborne microorganisms, which are adsorbed on dust smaller than $5 \mu \mathrm{m}$ (PM5) in diameter, are inhaled by respiration, and deposited in the respiratory tract or the lung of worker and animals. It may cause the respiratory disorders such as pneumonia, asthma, bronchitis and rhinitis (Donham et al., 1986; Bruce and Sommer, 1987; Crook et al., 1991; Olson and Bark, 1996).

Generation of gases released in a confined pig house originates from anaerobic degradation of pig manure stored in the pit below the floor, respiration of pig, and operation of ventilation system (Chang et al., 2001). Of the major gaseous compounds from a pig house, methane $\left(\mathrm{CH}_{4}\right)$ and carbon dioxide $\left(\mathrm{CO}_{2}\right)$ do not cause a risk to workers and pigs in terms of exposure limit (Verstegen et al., 1976;

\footnotetext{
* Corresponding Author: Hong L. Choi. Tel: +82-2-880-4808, Fax: +82-2-874-4808, E-mail: chlast@snu.ac.kr

${ }^{1}$ Dept. of Environmental Engr. University of Seoul, Seoul, Korea. Received July 12, 2004; Accepted December 27, 2004
}

Noblet et al., 1989). On the other hand, ammonia $\left(\mathrm{NH}_{3}\right)$ and hydrogen sulfide $\left(\mathrm{H}_{2} \mathrm{~S}\right)$ have toxic impact on workers and pigs, and bring about environmental nuisance as odorous compounds emitted from a pig house (Nordstrom and McQuitty, 1976; Coleman et al., 1991). Odor detection threshold of ammonia is $5-50 \mathrm{ppm}$. It can irritate mucous surfaces at 100-500 ppm causing severe eye irritation. At 2,000-3,000 ppm, it also causes coughing and frothing at the mouth with possible fatalities, and is fatal at 10,000 ppm and higher (Bruce, 1981). Stombaugh et al. (1969) showed ammonia was related with reduced appetite, convulsion, and irregular breathing of pigs.

Hydrogen sulfide has odor threshold of 0.01-0.7 ppm. One can get irritation in his eyes and respiratory tract, if exposed to $\mathrm{H}_{2} \mathrm{~S}$ of 50-100 ppm for an hour. Exposure to 150 ppm $\mathrm{H}_{2} \mathrm{~S}$ for 8-48 h can cause fatal effect. Finally, rapid death can be resulted in from the exposure to 700-2,000 ppm $\mathrm{H}_{2} \mathrm{~S}$ (Bruce, 1981). Robertson and Galbraith (1971) reported that pigs experienced the loss of appetite and photophobia after they were exposed to $20 \mathrm{ppm}_{2} \mathrm{~S}$ and vomiting and diarrhea with 50-200 ppm $\mathrm{H}_{2} \mathrm{~S}$.

As mentioned above, optimal control of aerial pollutants such as dust, airborne bacteria, ammonia, hydrogen sulfide and odor concentration in a confined pig houses could be an effective management to prevent respiratory disease and health problems in workers and pigs. So far, however, studies for aerial environment in a confinement have focused on proper control of indoor temperature and relative humidity through the operation of a mechanical ventilation system; mainly in terms of modulating basic indoor condition. Only a few studies measured levels of 
Table 1. The construction materials and their characteristics of the confined growing/finishing pig house

\begin{tabular}{ll}
\hline Location & Composition \\
\hline Roof material & Urethane $100 \mathrm{~mm}$ coated w/both sides of steel sheet $0.8 \mathrm{~mm}$ \\
Outside wall & Styrofoam $100 \mathrm{~mm}$ coated w/both sides of steel plate $0.8 \mathrm{~mm}$ \\
Inside wall (upper) & Styrofoam $50 \mathrm{~mm}$ coated w/both sides of steel plate $0.8 \mathrm{~mm}$ \\
Inside wall (lower) & Concrete $200 \mathrm{~mm}$ \\
Ceiling & Styrofoam $50 \mathrm{mmw} /$ both sides of steel plate $0.8 \mathrm{~mm}$ \\
Characteristics & Specification \\
Pit depth $(\mathrm{cm})$ & $45-60$ \\
Pit capacity $\left(\mathrm{m}^{3}\right)$ & 80.4 \\
Floor material & Concrete \\
Fan type & Sirocco fan \\
& - capacity of $8,360 \mathrm{~m}^{3} / \mathrm{h}$ at maximum \\
R value $\left(\mathrm{m}^{2} \mathrm{C} / \mathrm{W}\right)$ & $19.8 / 12.8$ \\
- Roof $/ \mathrm{wall}^{3}$ &
\end{tabular}

Table 2. Measurement specifications of the thermal environment factors and air pollutants

\begin{tabular}{llcc}
\hline Parameters & Measurement instrument & Sampling time & Measurement method \\
\hline Temperature & 6,242, Kanomax & - & - \\
Relative humidity & SK-110TRH, Sato & - & - \\
Odor concentration & Odor sensor (XP-329, Cosmos) & - & - \\
Ammonia $\left(\mathrm{NH}_{3}\right)$ & Ion Chromatography (761 Compact IC, Metrohm) & $30 \mathrm{~min}$. & NIOSH (1994) \\
Hydrogen sulfide $\left(\mathrm{H}_{2} \mathrm{~S}\right)$ & Ion Chromatography (761 Compact IC, Metrohm) & $30 \mathrm{~min}$. & NIOSH (1994) \\
Total dust & - & $1 \mathrm{~h}$ & NIOSH (1994) \\
Total airborne bacteria & - & $15-30 \mathrm{~min}$. & Thorne et al. (1992) \\
\hline
\end{tabular}

aerial environment factors emitted from a confined pig house (Bundy and Hazen, 1975; Curtis et al., 1975; Elliott et al., 1976; Seedorf et al., 1998; Takai et al., 1998). However these studies did not clearly show the origin of air pollutants and the dust distribution over space with air flow. To properly manage the indoor air quality in the confinement, the fundamental researches, which examine the relationship between air pollutants (i.e., dust, odor, gas, airborne bacteria) and thermal environment factors (e.g., temperature, and relative humidity) in the confinement, are desirable.

Thus, in this study the degree of statistical correlation beween generation of air pollutants and thermal environment factors, i.e., temperature and relative humidity in a confined pig house in winter was evaluated.

\section{MATERIALS AND METHODS}

\section{Experimental design}

The experiments were performed in a confined pig house, located at the Colligate Livestock Research Station, Seoul National University. The experiments were carried out for 60 days in January and February 2002, and the samples of air pollutants were taken every four days.

The confined growing-finishing pig house in this study was $20 \mathrm{~m}$ long, $12 \mathrm{~m}$ wide and $3 \mathrm{~m}$ high. It and has two rows, each of which contains ten pens in both sides from central alley with the concrete solid floor. Ten crossbred (Landrace $\times$ Yorkshire $\times$ Duroc) growing-finishing pigs with mean weight of $45 \mathrm{~kg}$ were housed randomly in the pens.
The pigs were fed by an automatic feeder and provided drinking water with nipples attached on a fence of the pen. During the entire experimental period, one infrared lamp of $620 \mathrm{~W}$ was installed in each pen to keep the pen warm in early growth phase of the growing pigs. The outside fresh air of winter was taken into through the slot inlet on the end wall of the house and warmed up when it traveled through the attic space and drawn into the both sides along the side wall of the house. The air flow was directed along the ceiling by the baffle hinged on the sidewall and controlled by the winch cables. The air was removed by the four exhaust fans each of which has maximum capacity of 8,360 $\mathrm{m}^{3} / \mathrm{h}$. They were installed on the one side of the wall, operated continuously at the minimum flow rate to mainly control moisture and airborne particulates in the confinement, as recommended by MWPS-8 (1988).

\section{Analysis and sampling method}

Air samples were collected using an air sampler (No. 800519, Gilian) to quantify ammonia, hydrogen sulfide, total dust, and total airborne bacteria. The sampling was performed at three different location of the confinement (i.e., at the center and both sides of the house). Sampling height was $0.3 \mathrm{~m}$ high from the floor. Air samples were collected at the flow rate of $1.5-2 \mathrm{~L} / \mathrm{min}$ except for total airborne bacteria. Air sample for bacteria was collected at 12.5 $\mathrm{L} / \mathrm{min}$. Air sampling time for air pollutants is given in Table 2. Measurements of temperature, relative humidity and odor concentration were made at the same sampling sites three times a day; morning (8:00-9:00 am), afternoon (2:00-3:00 
pm), and evening (8:00-9:00 pm). The measurement time bands were carefully determined to avoid disturbances (i.e., particulates emitted by feeding) and to relate pig activity with time in a day. Table 2 shows the method, device and sampling time, used for analysis of environmental factors in the confinement.

\section{Statistical analysis}

SAS software (1996) was used to evaluate correlation between different parameters in this study.

\section{RESULTS AND DISCUSSIONS}

\section{Fluctuations of air pollutants in the confined pig house} with time bands in winter

Figure 1 shows the profiles of air pollutant concentrations in January and February, 2002. Mean concentrations of the 16 measurements in air pollutants were $1.04( \pm 0.39) \mathrm{mg} / \mathrm{m}^{3}$ in the morning (8:00-9:00 am), $2.53( \pm 1.02) \mathrm{mg} / \mathrm{m}^{3}$ in the afternoon $(2: 00-3: 00 \mathrm{pm})$ and $1.83( \pm 0.64) \mathrm{mg} / \mathrm{m}^{3}$ in the evening $(8: 00-9: 00 \mathrm{pm})$. The mean counting numbers of total airborne bacteria were $10^{4.58}\left( \pm 10^{0.17}\right) \mathrm{CFU} / \mathrm{m}^{3}, 10^{5.65}\left( \pm 10^{0.70}\right) \mathrm{CFU} / \mathrm{m}^{3}$ and $10^{5.02}$ $\left( \pm 10^{0.38}\right) \mathrm{CFU} / \mathrm{m}^{3}$ in the morning, afternoon, and evening, respectively. The concentrations of ammonia and hydrogen sulfide were, respectively, $9.14( \pm 0.94) \mathrm{ppm}$ and 22.86 $( \pm 1.48) \mathrm{ppb}$ in the morning, $12.59( \pm 1.83) \mathrm{ppm}$ and 42.20 $( \pm 4.62) \mathrm{ppb}$ in the afternoon, and $11.84( \pm 0.87) \mathrm{ppm}$ and $36.75( \pm 2.83) \mathrm{ppb}$ in the evening. The mean odor concentrations were $182.84( \pm 18.67), 244.10( \pm 29.23)$, and $216.00( \pm 20.29)$, respectively.

In general, levels of all the air pollutants (i.e., total dust, total airborne bacteria, ammonia, hydrogen sulfide and odor concentration) in the confined pig house were at the peak in the afternoon (2:00-3:00 pm), subsequently followed by the evening (8:00-9:00 pm) and morning (8:00-9:00 am). It may be attributed to increased activities of pigs at warm inside temperature in the afternoon. That is, airborne particulates, which were originated from feces and residual feeds and deposited in dry state on the floor, were dispersed into aerial space by frequent movement of the pigs. Similar results were also obtained in the others' works (Pederson, 1993; van't Klooster et al., 1993; Gustafsson, 1994).

Because on dusts released into the aerial space in the confinement the gaseous compounds and airborne microorganisms can be easily adsorbed on (Straubel, 1981; Janni et al., 1984; Hartung, 1986; Hinz and Krause, 1988), the elevated concentration of air pollutants during the day time is reasonable. Dry feces and residual feeds adhered to pigs' skin during their activities may also contribute to increase of the dust and odor in a confined pig house. It was observed that most pigs lay down and did not move actively

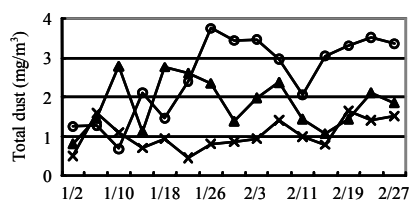

Day

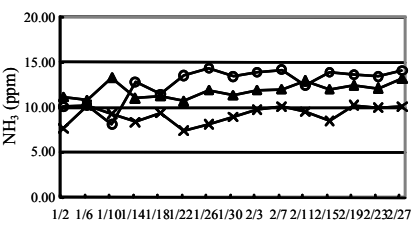

Day

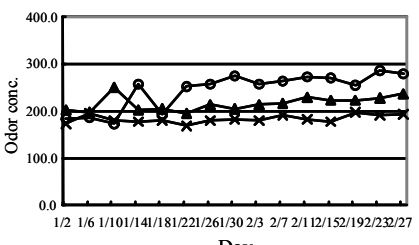

Day

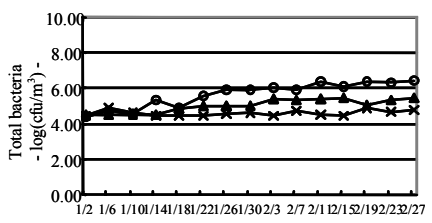

Day

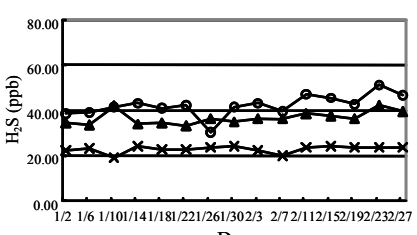

Day
Figure 1. Fluctuation of air pollutants (total dust, total bacteria, $\mathrm{NH}_{3}, \mathrm{H}_{2} \mathrm{~S}$, Odor) in the confined pig house at time (* 8:00-9:00 am, $\rightarrow$ 2:00-3:00 pm, $\rightarrow-8: 00-9: 00 \mathrm{pm}$ )

in the morning. Activities of pigs also withered as indoor temperature declined rapidly in the evening. This fact demonstrates the pig activity relates to the surrounding temperature, so does the concentration of dusts and odor. When this study was carried out, any human activity was not allowed to eliminate its effect on the generation of air pollutants in the confined pig house.

Compared with the previous studies (Bundy and Hazen, 1975; Curtis et al., 1975; Elliott et al., 1976; Seedorf et al., 1998; Takai et al., 1998), the concentrations of air pollutants presented in this study were higher, on the whole. This is mainly because, first, the confined pig house was not cleaned up for the entire experiment period, so the net concentration of indoor air pollutants accumulated with time although ventilation was provided; the ventilation rate was minimal. Second, the ventilation system was operated at the same rate during the sampling periods (i.e., 8:00-9:00 am, 2:00-3:00 pm and 8:00-9:00 pm) in order to eliminate the effect of ventilation rate on the behavior of air pollutant levels in the confined pig house. As a result, the measured concentrations of the air pollutants in this study were higher, especially in the afternoon, than conventional confined pig houses ventilation rates of which are carefully controlled to maintain the optimal indoor temperature.

\section{Fluctuations of the thermal environmental factors (temperature and relative humidity) in the confined pig house}

Figure 2 and 3 show the concentration profiles of air pollutants (i.e., total dust, total airborne bacteria, ammonia, hydrogen sulfide, odor concentration) with regard to indoor temperature and relative humidity in the confinement, 

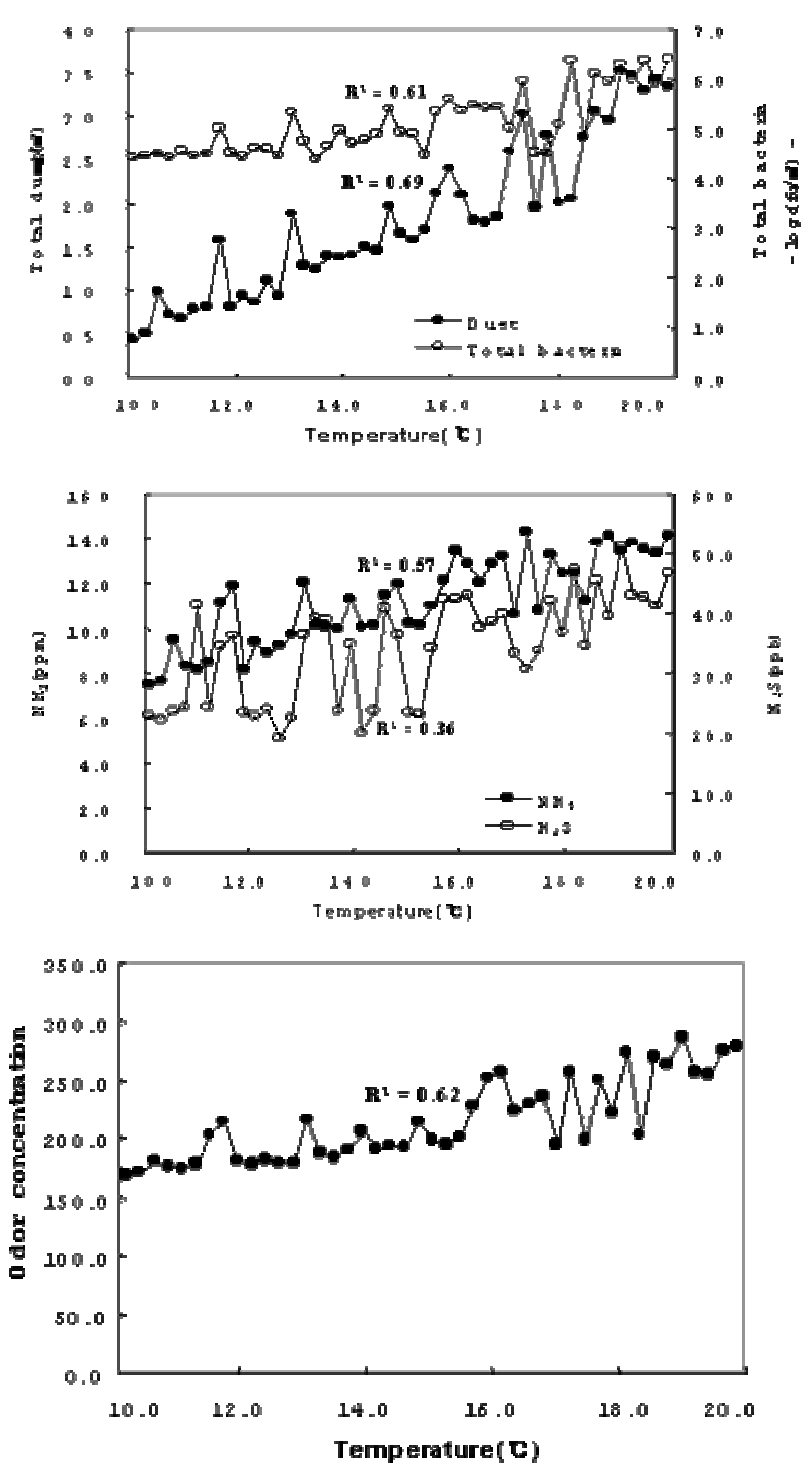

Figure 2. Relationship of air pollutants (total dust, total bacteria, $\mathrm{NH}_{3}, \mathrm{H}_{2} \mathrm{~S}$, odor) with temperature in the confined pig house.

respectively. During the experimental period, the indoor temperature ranged from $10^{\circ} \mathrm{C}$ to $20^{\circ} \mathrm{C}$, generally complying with the range of $15^{\circ} \mathrm{C}-21^{\circ} \mathrm{C}$; optimal level of indoor temperature, suggested by MWPS (1998). In general, the indoor temperature showed positive correlation with the concentration of pollutants. Correlation coefficient (R) of indoor temperature with total dust was 0.69 ; with airborne bacteria 0.61 ; with ammonia 0.57 ; with hydrogen sulfide 0.36 ; with odor concentration 0.62 . Total dust was highly correlated with indoor temperature, while hydrogen sulfide less. Indoor relative humidity varied from $65 \%$ to $90 \%$ during the experimental period and was a little higher, compared to optimal range for pigs. Trends of correlation between indoor relative humidity and air pollutants were generally negative. The correlation coefficient $(\mathrm{R})$ of indoor relative humidity was -0.52 with the total dust, -0.30 with
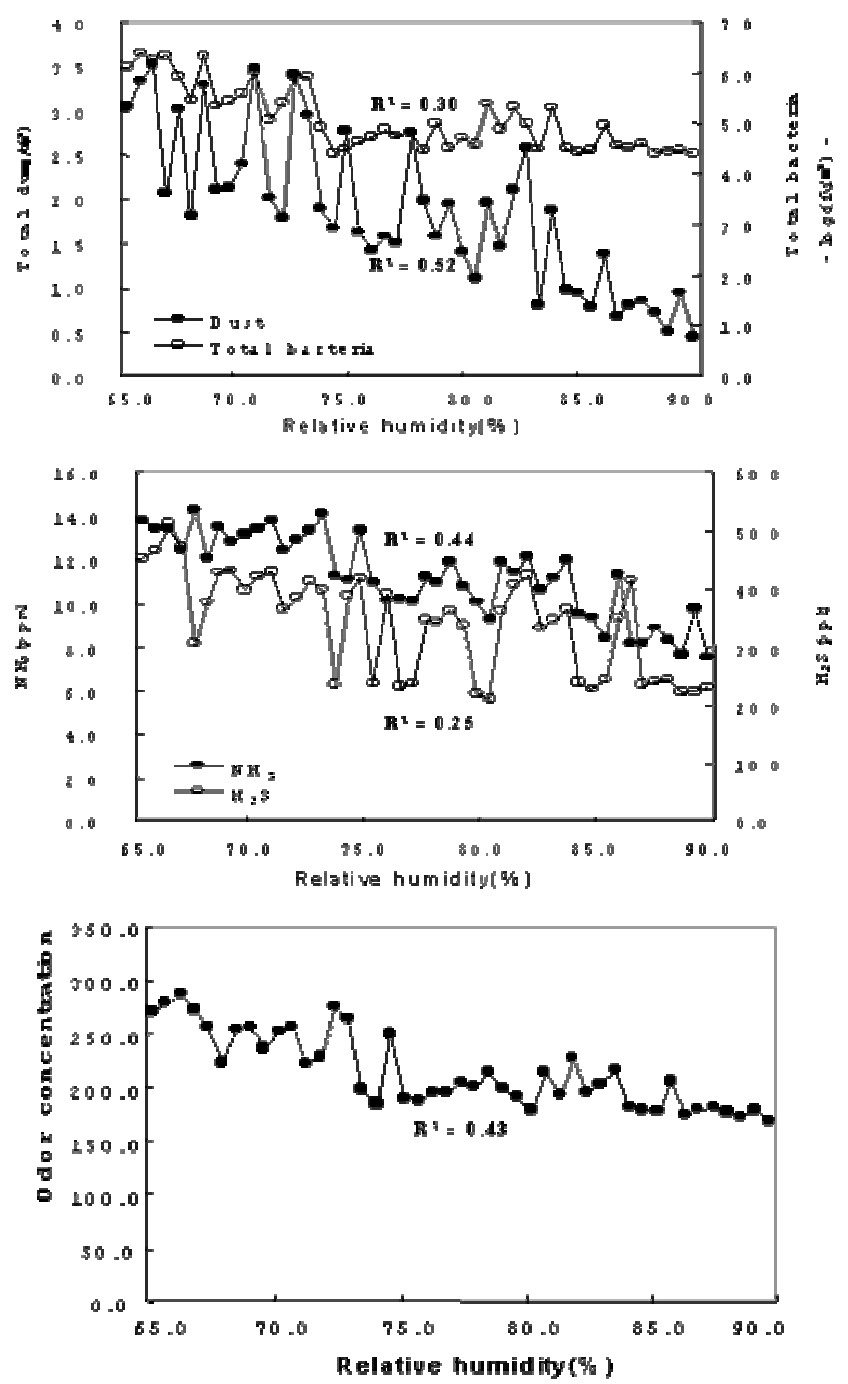

Figure 3. Relationship of air pollutants (total dust, total bacteria, $\mathrm{NH}_{3}, \mathrm{H}_{2} \mathrm{~S}$, Odor) with relative humidity in the confined pig house; $50-70 \%$, recommended by MWPS (1998).

total airborne bacteria, -0.44 with ammonia, -0.25 with hydrogen sulfide and -0.43 with the odor concentration. This indicated that value of correlation coefficient of indoor relative humidity was the highest with total dust and the lowest with hydrogen sulfide. It seems to attribute to high water vapor concentration which may adsorb the dust particles and $\mathrm{H}_{2} \mathrm{~S}$ compounds in the confinement although their adsorption rates may differ.

\section{Correlation between air pollutants and thermal environment factors (temperature and relative humidity) in the confined pig house}

Table 3 shows the degree of correlation between air pollutants and temperature and between the former and relative humidity in the confined pig house. It was proven that correlations between total dust and total bacteria, total dust and ammonia, total dust and odor concentration, total dust and relative humidity, temperature and total bacteria, 
Table 3. Correlations among air pollutants, temperature and relative humidity observed in the a confined pig house

\begin{tabular}{|c|c|c|c|c|c|c|c|}
\hline Variable & Temperature & Relative humidity & Odor concentration & $\mathrm{NH}_{3}$ & $\mathrm{H}_{2} \mathrm{~S}$ & Total dust & Total bacteria \\
\hline Temperature & 1.00 & & & & & & \\
\hline Relative humidity & -0.24 & 1.00 & & & & & \\
\hline Odor concentration & $0.62 *$ & -0.43 & 1.00 & & & & \\
\hline $\mathrm{NH}_{3}$ & $0.57 *$ & -0.44 & $0.55^{*}$ & 1.00 & & & \\
\hline $\mathrm{H}_{2} \mathrm{~S}$ & 0.36 & -0.25 & 0.44 & 0.28 & 1.00 & & \\
\hline Total dust & $0.69 * *$ & $-0.52 *$ & $0.62 *$ & $0.64 *$ & 0.36 & 1.00 & \\
\hline Total bacteria & $0.61 *$ & -0.30 & 0.42 & 0.43 & 0.31 & $0.57 *$ & 1.00 \\
\hline
\end{tabular}

Ref) significant $\rightarrow * \mathrm{p}<0.05, * * \mathrm{p}<0.01$

temperature and ammonia, temperature and odor concentration, and odor concentration and ammonia were statistically significant $(\mathrm{p}<0.05)$. Correlation between total dust and temperature was statistically very significant $(\mathrm{p}<0.01)$. As a result of statistical test, the significant level of total dust for other air pollutants was relatively high, which may be caused by:

When indoor environmental condition is maintained at higher temperature and lower relative humidity, pigs are more active, feedstuff left in feeder and manure deposited on the floor drier. It may generate more dust in the confined pig house. Dust particles suspended into the aerial space easily adsorb airborne microbes, gaseous and odorous compounds which are originated from manure deposited on the floor and stored in the pit underneath the floor. They are easily dispersed in the confinement or settle on the floor (Straubel, 1981; Janni et al., 1984; Hartung, 1986; Hinz and Krause, 1988). In short, increase in dust generation causes odor and airborne microbes to increase.

Odorous compounds adsorbed on dust are transferred to mucous membrane in the nose of worker and raise the level of nuisance by odor. Airborne microorganisms, also, are adsorbed on the dust smaller than $5 \mu \mathrm{m}$ in diameter, inhaled by respiration, and deposited in the respiratory tract or the lung of workers and pigs. This induces the respiratory disorders such as pneumonia, asthma, bronchitis, and rhinitis (Donham et al., 1986; Bruce and Sommer, 1987; Crook et al., 1991; Olson and Bark, 1996). Therefore, dusts generated in a confined pig house should be controlled in order to effectively reduce odor concentration and risk of infection with the respiratory disease for workers and pigs. Further studies related to livestock environment are needed to conduct not only for well-being of livestock but also for preventing the respiratory disease and to lessen the level of nuisance caused by odor.

Based on the statistical analyses, hydrogen sulfide was not significantly correlated to other factors. Generally it tends to be adsorbed rather on dust but has a specific gravity heavier than air, and is deposited easily. It is reported to represent high concentration mainly on the surface of manure stored in the pit under the floor (Shurson et al., 1997). Considering this molecular characteristics of hydrogen sulfide, therefore, the experimental results appear not to explain accurate concentration of hydrogen sulfide emitted from the confined pig house due to sampling on the site $30 \mathrm{~cm}$ away from the floor. On the other hand, this statistical analyses illustrates that adsorptive capacity of dust with hydrogen sulfide is lower than that with ammonia.

\section{CONCLUSION}

The level of emissions of air pollutants in the confined pig house was observed higher at 2:00-3:00 pm, followed by those at 8:00-9:00 pm and 8:00-9:00 am. Total dust was proved to have a statistically significant correlation with other factors $(p<0.05)$ and especially very significant correlation with temperature $(\mathrm{p}<0.01)$. This implicates that dust is a carrier of air pollutants originated from the confined pig house. It was analysed that adsorptive capacity of dust on ammonia and hydrogen sulfide, principal odorous compounds emitted from the confined pig house, is higher in ammonia than hydrogen sulfide.

\section{REFERENCE}

Aarnink, A. J. A., P. F. M. M. Roelofs, H. Ellen and H. Gunnink. 1999. Dust sources in animal houses. Proceedings on dust control in animal production facilities. Department of Agricultural Engineering, Danish Institute of Agricultural Sciences, Horsens, Denmark, pp. 34-40.

Barth, C. L., L. F. Elliot and S. W. Melvin. 1984. Using odor control technology to support animal agriculture. Transactions of the ASAE. 27:859-864.

Bottcher, R. W. 2001. An environmental nuisance: odor concentrated and transported by dust. Chemical Senses 23:327-331.

Bruce, J. M. 1981. Ventilation and temperature control criteria for pigs, In: Environmental Aspects of Housing for Animal Production. Butterworths, London, pp. 197-216.

Bruce, J. M. and M. Sommer. 1987. Environmental aspects of respiratory disease in intensive pig and poultry houses, Including the implications for human health. Proceedings EC Meeting Aberdeen, 29-30 October 1986. EC Commission Publications, Brussels.

Bundy, D. S. and T. E. Hazen. 1975. Dust levels in pig confinement systems associated with different feeding methods. Transactions of the ASAE. 18(1):137-139, 144.

Carpenter, G. A., A. W. Cooper and G. E. Wheeler. 1986. The effect of air filtration on air hygiene and pig performance in 
early-weaner accommodation. Animal production. 43:505-515.

Chang, C. W., H. Chung, C. F. Huang and H. J. Su. 2001. Exposure assessment to airborne endotoxin, dust, ammonia, hydrogen sulfide and carbon dioxide in open style pig houses. Annals of Occupational Hygiene. 45(6):457-465.

Clark, S., R. Rylander and L. Larsson. 1983. Airborne bacteria, endotoxin and fungi in dust in poultry and pig confinement buildings. American Industrial Hygiene Association Journal 44:537-541.

Coleman, R. N., J. J. R. Feddes and B. S. West. 1991. What is odour and the potential for its control? In: Proceedings Western Branch Meeting. Canadian Society of Animal Production, Chilliwack (Abstr.).

Crook, B., J. F. Robertson, G. S. Travers, E. M. Botheroyd, J. Lacey and M. D. Topping. 1991. Airborne dust, ammonia, microorganisms and antigens in pig confinement houses and the respiratory health of exposed farm workers. American Industrial Hygiene Association Journal 52:271-279.

Curtis, S. E., J. G. Drummond, K. W. Kelley, D. J. Grunloh, V. J. Meares, H. W. Norton and A. H. Jensen. 1975. Diurnal and annual fluctuations of aerial bacterial and dust levels in confined pig houses. J. Anim. Sci. 41(5):1502-1511.

Donham, K., L. J. Scallon and W. Popendorf. 1986. Characterization of dusts collected from pig confinement buildings. American Industrial Hygiene Association Journal 47:404-410.

Elliot, L. F., T. M. McCalla and J. A. Deshazer. 1976. Bacteria in the air of housed pig units. Applied and Environmental Microbiology 32(2):270-273.

Gustafsson, G. 1994. Efficiency of different dust reducing methods in pig houses. Proceedings of the 12th CIGR-Conference, 5-8 September, 1994. Milano, CIGR, Merelbeke, Belgium, pp. 551-558.

Hartung, J. 1986. Dust in livestock buildings as a carrier of odours. In: (Ed. V. C. Nielsen, J. H. Voorburg and P. L'Hermite), Odour Prevention and control of organic sludge and livestock farmings. Elsevier, London, pp. 321-332.

Henschler, D. 1990. Maximale Arbeitsplatzkonzentrationen und biologische Arbeitsstoffoleranzwerte. Mitteilung der Senatskommission zur Prufung Gesundheitsschadlicher Arbeitsstoffe; 26. VCH Verlagsgesellschaft, Weinheim, Germany.

Hinz, T. and K. H. Krause. 1988. Emission of respiratory biological-mixed-aerosols from animal houses, In: Environmental aspects of respiratory disease in intensive pig and poultry houses, including the implications for human health, pp. 81-89. Proceedings: EEC-Meeting Aberdeen, 29-30 October, 1986.

Hsia L. C. and G. H. Lu. 2004. The effect of high environmental temperature and nutrient density on pig performance, confromation and carcass characteristics under unrsticted feeding system. Asian-Aust. J. Anim. Sci. 17(2):250-258

Hsia L. C.2004. Effect of food deprivation length of pair house pigs on the running speed and feeding activity in solidatary and social conditions. Asian-Aust. J. Anim. Sci. 17(2):271-277

Janni, K. A., P. T. Redig, J. Newman and J. Mulhausen. 1984. Respirable aerosol concentrations in turkey grower buildings. ASAE paper No. 84-4522, St. Joseph, MI.

Kim, K., H. L. Choi ${ }_{2}$ H. Ko and C. N. Kim. 2004. Comparison of Analysis Methods of Ammonia from Pig Production Facilities.
Asian-Aust. J. Anim. Sci. 17(11):1608-1614

Marielena M. L. and L. C. Hsia.2004. Effect of season, hosing and physiological stage on drinking and other related behavior of dairy cows (Bos taurus) Asian-Aust. J. Anim. Sci. 17(10):1417-1429

MWPS. 1988. Pig housing and equipment handbook, MWPS-8. Midwest Plan Service. Iowa State University, Ames, IA 50011.

National Institute for Occupational Safety and Health. 1994. NIOSH Manual of Analytical Method. Cincinnati, Ohio, 4th Ed.

Noblet, J., H. Fortune, S. Dubois and V. Henry. 1989. Nouvelles bases d'estimation des teneur en energie digestible metabolisable et nette des aliments pourle porc. INRA, Paris, pp. 1-106.

Nordstrom, G. A. and J. B. McQuitty. 1976. Manure Gases in the Animal Environment. Department of Agricultural and Engineering, University of Alberta.

Olson, D. K. and S. M. Bark. 1996. Health hazards affecting the animal confinement farm worker. Am. Assoc. Occup. Health Nurse J. 44:198-204.

Pedersen, S. 1993. Time-based variation in airborne dust in respect to animal activity. Proceedings on Livestock Environment. pp. 718-726. ASAE, St. Joseph, MI.

Robertson, A. M. and H. Galbraith. 1971. Effect of Ventilation on the Gas Concentration in a Part-stalled Piggery. R and D Studies 1, Scottish Farm Buildings Investigation Unit, pp. 1728.

SAS. 1996. User's Guide: Statistics, Version 6.0 ed., SAS Inst., Inc., Cary, NC. USA.

Seedorf, J., J. Hartung, M. Schroder, K. H. Linkert, V. R. Phillips, M. R. Holden, S. W. Sneath, J. L. Short, R. P. White, S. Pederson, H. Takai, J. O. Johnsen, J. H. M. Metz, P. W. G. Koerkamp, G. H. Uenk and C. M. Wathes. 1998. Concentrations and emissions of airborne endotoxins and microorganisms in livestock buildings in Norther Europe. J. Agric. Engin. Res. 70:97-109.

Shurson, J., M. Whitney and R. Nicolai. 1997. Nutritional manipulation of pig diets to reduce hydrogen sulfide emissions. Extension service, Univ. of Minnesota.

Stombaugh, D. P., H. S. Teague and W. L. Roler. 1969. Effect of atmospheric ammonia in the pig. J. Anim. Sci. 28:844-847.

Straubel, H. 1981. Elektro-optische Messung von Aerosolen. Technisches Messen. 48:199-210.

Takai, H., S. Pederson, J. O. Johnsen, J. H. M. Metz, P. W. G. Koerkamp, G. H. Uenk, V. R. Phillips, M. R. Holden, R. W. Sneath, J. L. Short, R. P. White, J. Hartung, J. Seedorf, M. Schroder, K. H. Linkert and C. M. Wathes. 1998. Concentrations and emissions of airborne dust in livestock buildings in Norther Europe. J. Agric. Enginee. Res. 70:59-77.

Thorne, P. S., M. S. Niekhaefer, P. Whitten and K. J. Donham. 1992. Comparison of bioaerosol sampling methods in barns housing pig. Appl. Environ. Microbiol. Aug, pp. 2543-2551.

van't Klooster, C. E., P. F. M. M. Foelofs and P. A. M. Gijsen. 1993. Positioning air inlet and air outlet to reduce dust exposure in pig buildings. Proceedings on Livestock Environment IV, pp. 754-761. ASAE, St. Joseph, MI. Verstegen, M. W. A., W. Van Der Hel, A. A. Jongebreur and G. Enneman. 1976. The influence of ammonia and humidity on activity and energy balance data in groups of pigs. Zeitschrift fur Tierphysiologie, Tierernahrung and Futtermittelkunde. 37:225-263. 